\title{
Proposal for Safety Inspection of Multiple Dwellings in the Era of Sustainability
}

\author{
Sang-Hoon Park ${ }^{1}$, Cheonghoon Baek ${ }^{2, *}$ and Dong-Keon Kim ${ }^{3}$ \\ ${ }^{1}$ Brain Korea (BK) 21 Research Team, Yonsei University, 50 Yonsei-Ro, Seodaemun-Gu, Seoul,120-749, Republic of Korea \\ ${ }^{2}$ Korea Institute of Construction Technology, 2311, Daewha-dong, Ilsan-gu, Goyang-si, Gyeonggi-do, Republic of Korea \\ ${ }^{3}$ Central Research Institute, Korea Hydro \& Nuclear Power, 70, 1312 Beon-gil, Yuseong-daero, Yuseong-gu, Daejeon 305-343, \\ Republic of Korea
}

Received: 13 Jul. 2013, Revised: 26 Nov. 2013, Accepted: 27 Nov. 2013

Published online: 1 Jan. 2014

\begin{abstract}
In this paper, methods to institute a sustainable safety inspection system for extent multiple dwellings in Korea are presented. The results of the study are summarized below.

First, on the basis of a study on the safety inspection systems for multiple dwellings in Japan and the United States, the state of the safety inspection systems and the policies for multiple dwellings in Korea is examined. Subsequently, the weaknesses of the Korean safety inspection systems and the need to revise them are discussed.

Second, the housing circumstances in Korea, Japan, and the United States are analyzed and compared, including laws on safety inspection for multiple dwellings, targets and items of inspection, qualifications for inspection, building history systems, and qualified professionals for safety inspection. On the basis of the analysis and comparison, the differences between the systems of the three nations and the issues that need to be introduced in Korea are presented.

Third, based on the safety inspection experiences in Japan and the United States, new directions of safety inspection and methods to enhance current systems for multiple dwellings in Korea are proposed.
\end{abstract}

Keywords: Existing Multiple Dwellings, Safety Inspection, Building History Information

\section{Introduction}

\subsection{Background and Objective of Research}

The Korean government has initiated housing supply policies that tend to focus on new construction, and thus, an enormous number of housing units were built in a fairly short period. In the 1970s, as a means for economic growth, the Housing Construction Promotion Act was enacted to supply housing units. As a result of such housing policies, there has been a massive amount of housing construction: five million housing units built in the beginning of the 1980s and two million units built in and around Seoul, including Bundang and Ilsan (the first new town) in the 1990s [1].

This housing supply policy has brought an oversupply of housing units in the 2000 s. The housing supply rate reached $110 \%$ [2] and unsold new apartments have become a serious social issue. Specifically, the excessive supply of houses constructed between the 1980s and the 1990 s has caused nearly $80 \%$ of the total multiple dwellings to be approximately twenty years old[3]. Maintenance, rehabilitation, and safety inspection of houses have thus become social concerns.

The developed nations of the world have implemented green policies, like energy saving, and made efforts to upgrade housing amenities for improving quality of life. Due to recent social changes, such as an increase in national income, low birth rates, and improvement in the quality of life, the Korean government has sought to shift from a policy of quantitative housing supply to rehabilitation of existing housing units. Korea also created a national vision, Low Carbon and Green Growth, in 2008 and began to take an interest in the control of reconstruction, redevelopment, and housing under sustainable development [4].

Despite the social demands for rehabilitation of existing houses, improvement in the quality of life, and

\footnotetext{
*Corresponding author e-mail: archihoony@ gmail.com
} 
energy saving, the inspection systems for the safety and maintenance of buildings in Korea were focused only on the structural performance of buildings.

Consequently, the national housing policies have thus far been in agreement with a number of institutions for housing supply, with little consideration for rehabilitation of existing units and improvement in the quality of life.

Japan formulated the Basic Law for Housing Life in 2006, and according to the law, its national policies shifted to be market-oriented and more concerned with the existing stock of housing. The nation has responded actively to changes in the housing environment, for example, by revising housing policies to encourage maintenance of existing houses rather than construction [5].

Within the framework of rehabilitation of existing houses as well as construction, New York City in the United States has operated various systems to encourage safety and maintenance of its large housing stock and to attain its political goals [6].

Ideally, an owner should voluntarily maintain their house; however, the nation must establish minimum criteria and enforce housing maintenance in case of a threat to the life and housing environment of the public. From this point of view, the criteria a nation has for housing maintenance is important. Therefore, this study sought to analyze and compare the sustainable safety inspection systems for multiple dwellings of Korea, Japan, and the United States, and to propose methods for improving the safety inspection system of Korea.

\subsection{Objects and Methods of Research}

In this study, the safety inspection for multiple dwellings stipulated in the relevant laws of Korea, Japan, and the United States was researched. The relevant laws included the Housing Act and the Special Law for Facility Safety (SLFS) of Korea, the Building Standard Act of Japan, and the Housing Maintenance Code and the Building Code of New York City.

The related organizations were found through study of the relevant literature, and on-site surveys and interviews with the people involved were conducted so as to assess the current situation and challenges of safety inspection. The interviewees in Korea were professionals of the Korea Infrastructure Safety \& Technology Corporation, Korea Land \& Housing Corporation, and Korea Institute of Construction Technology. In New York, the Department of Building (DOB), Community Associations Institute (CAI), and Institute of Real Estate Management (IREM) were visited for interviews and surveys. The Tokyo Metropolitan Government, the Japan Building Disaster Prevention Association, Building and Equipment Life Cycle Association (BELCA), and Tokyo Metropolis Disaster Prevention Machizukuri Center were visited to collect practical materials on safety inspection in Japan. These efforts were made to analyze and compare the safety inspection activities of Korea, Japan, and the United States, and to present methods to ameliorate the circumstances in Korea that demand institutional changes.

\section{Policies of Korea, Japan, and The United States for Multiple Dwellings}

The housing policies of the United States have consistently been for low- and middle-income families, and particularly, the recent policies were to maintain the governments direct investment but also to use private sectors with effectiveness [7]. New York City has a framework of housing policies that covers rehabilitation of existing houses as well as construction, and has given priority to policies that consider not only the safety of its large housing stock but also the residents quality of life.

The housing policies of Japan, after the Second World War, were mainly concerned with government-initiated housing supply. However, the nation formulated the Basic Law for Housing Life in 2006, which has put focus on market-orientation and the existing stock of housing. The national housing policies have changed to support the rehabilitation of existing houses, for instance, political measures against aging society, housing reformation, and promotion of existing houses. In addition, the policies on safety inspection of buildings consider both improved quality of life and safety of residents.

The Korean War severely damaged the key industries and houses of Korea; therefore, most of the housing policies were state-sponsored programs to supply houses and solve the housing shortage. In the 2000s, the excessive supply of houses and social changes, such as low birth rates and improved quality of life, have raised the political issue of how houses should be rehabilitated while considering both safety and quality of life.

\section{Current State of Safety Inspection Systems For Multiple Dwellings}

\subsection{The United States}

New York City applies the Housing Maintenance Code and Article 6 (Maintenance) of the Building Code to manage the housing environment of citizens and the safety of buildings $[8,9,10]$.

The Housing Maintenance Code defines minimum criteria for health of residents, safety, fire protection, lighting, repair, and maintenance. If the condition of a house is below the minimum criteria, the lessee can report it to the city or borough office, which encourages the house owner to maintain the house.

Article 6 (Maintenance) of the Building Code has provisions for permission of house or building construction, construction procedures, and other requirements for construction and maintenance, and 
specifically requires a house owner to conduct a safety inspection for exterior walls and appurtenances once every fifth year.

Inspection of exterior walls and appurtenances is divided into inspection of external space, internal space, underground space, and general inspection or condition of a building. A qualified architect or engineer is allowed to carry out the safety inspection.

Records of the safety inspections are collected in a building history information system per state or major city. New York City stipulates that the history of a building, including safety inspection, permission of construction, and other overall issues, be entered in the Buildings Information Systems (BIS). For buildings greater than five-stories in New York City, it is compulsory to submit a report of safety inspection once every fifth year and the city must receive building data from the owners and operate a record management system that covers an overview of the building, inspection history, etc.[11].

This building history information system of the city has been advantageous in forming reasonable housing prices and promoting sound distribution in the purchase and sale of existing houses (Table1).

\subsection{Japan}

Article 8 of the Building Standard Act of Japan stipulates that the site, structure, and facilities of a building should be maintained at an appropriate level of quality by the owner thereof [12]. Quasi-public buildings and buildings used by many and unspecified persons are the target of safety inspection reporting, and the site, structure, and facilities of such buildings designated by a corresponding administrative agency are inspected. The Housing Administration of the Ministry of Construction (1985) enforces a report of regular inspection in accordance with Article 12 of the Building Standard Act, which determines the items for regular inspection, at a designated time which varies from every six months to three years based on the purposes of buildings. Multiple dwellings with more than five floors and an area larger than 1,000 square meters are inspected every third year. For escalators and other building facilities, the relevant laws (the Fire Services Act, the Waterworks Law, etc.) require regular inspection every sixth month (Table 2).

First-class or second-class certified architects or those who meet the requirements of the Ministry of Land, Infrastructure, Transport and Tourism can conduct regular inspection for special structures [13].

In addition, Japan has a building information history system, Mansion Mirai Net, which covers the complete information of buildings including data of regular inspection. The purpose of the system is to foster proper maintenance of mansions and to promote circulation of existing mansions. The Mansion Management Center built the system in 2006 through sponsorship by the
Table 1: Overview of New York's BIS system

\begin{tabular}{|c|c|}
\hline Item & Contents \\
\hline Subject system & BIS (Building Information System) \\
\hline Legal ground & Building Code Article 6 Maintenance \\
\hline Objective & $\begin{array}{l}\text { Check building safety and violation, } \\
\text { history management }\end{array}$ \\
\hline Subject & Six stories or above \\
\hline $\begin{array}{l}\text { Submitted } \\
\text { document }\end{array}$ & Safety check report \\
\hline Submitted type & Paper based \\
\hline Function & $\begin{array}{l}\text { Administrations required for building } \\
\text { construction management, and safety } \\
\text { and maintenance of building after } \\
\text { construction completion }\end{array}$ \\
\hline $\begin{array}{l}\text { Whether } \\
\text { information is } \\
\text { open or not }\end{array}$ & Entirely open \\
\hline \multirow[t]{3}{*}{ Performance } & \\
\hline & $\begin{array}{l}\text {-Transparency is acquired, and the } \\
\text { time for waiting for document } \\
\text { issuance is dramatically reduced } \\
\text { (from } 2 \mathrm{~h} \text { to } 5 \text { min) through the } \\
\text { release of building information. } \\
\text {-History information on building } \\
\text { management and various periodic } \\
\text { inspections of some 950,000 } \\
\text { buildings can be checked. } \\
\text {-Employee productivity is } \\
\text { improved, and citizen services } \\
\text { are reinforced. }\end{array}$ \\
\hline & $\begin{array}{l}\text { NOTE: The page views of BIS } \\
\text { increased dramatically (from } 15,000 \\
\text { cases in } 2002 \text { to } 345,000 \text { cases in } 2005 \text { ) }\end{array}$ \\
\hline
\end{tabular}

Ministry of Land, Infrastructure, Transport and Tourism. The system targets common housing units, regardless of the number of floors and building area, and details brief descriptions of buildings, management rules, commissioned management and operation of community associations, accounting, repair plans, history, etc. Thus, the system is organized to inform users not only of the history of regular inspection but also of the overall history of the building [14].

\subsection{Korea}

In Korea, regular inspection for multiple dwellings is regulated by the Housing Act and SLFS. The Housing Act stipulates that a multiple dwelling with more than 300 families, or with more than 150 families and equipped with elevators or a central heating system should be under safety inspection and maintenance. According to the act, such dwelling units should have housing managers who deal with both engineering and management issues, like 
Table 2: Tyep, Size and Inspection TIme of Special Structures

\begin{tabular}{|c|c|c|}
\hline Purpose & Size & Inspection Time \\
\hline Buildings & & \\
\hline Cinema, image exhibition hall or theater & $\begin{array}{l}\mathrm{F} \geq 3 \text { and } \mathrm{A} \geq 200 \mathrm{~m}^{2} \text { or buildings with the main } \\
\text { stairway on floors other than the } 1 \text { st floor }\end{array}$ & Every 1 year \\
\hline Show room, public hall or meeting hall & $\mathrm{F} \geq 3$ or $\mathrm{A} \geq 200 \mathrm{~m}^{2}$ & Every 1 year \\
\hline $\begin{array}{l}\text { Hospital, clinic, nursing home, child welfare } \\
\text { institution, etc. }\end{array}$ & $\mathrm{F} \geq 3$ or $\mathrm{A} \geq 300 \mathrm{~m}^{2}$ & Every 3 years \\
\hline Motel or hotel & $\mathrm{F} \geq 3$ or $\mathrm{A} \geq 300 m^{2}$ & Every 3 years \\
\hline $\begin{array}{l}\text { Boarding house, multiple dwelling or } \\
\text { dormitory }\end{array}$ & $\mathrm{F} \geq 5$ or $\mathrm{A} \geq 1000 m^{2}$ & Every 3 years \\
\hline School or gymnasium & $\mathrm{F} \geq 3$ or $\mathrm{A} \geq 2,000 \mathrm{~m}^{2}$ & Every 3 years \\
\hline Museum, art gallery, library, etc. & $\mathrm{F} \geq 3$ or $\mathrm{A} \geq 2,000 \mathrm{~m}^{2}$ & Every 3 years \\
\hline $\begin{array}{l}\text { Department store, supermarket, exhibition } \\
\text { center, restaurant, or shop }\end{array}$ & $\mathrm{F} \geq 3$ or $\mathrm{A} \geq 500 \mathrm{~m} 2$ & Every 3 years \\
\hline Business, etc. & $\mathrm{F} \geq 5, \mathrm{~A} \geq 1,000 \mathrm{~m}^{2}$ & Every 3 years \\
\hline Elevators & - & Every 6 months \\
\hline Building Facilities & - & Every 6 months \\
\hline
\end{tabular}

Note) Situation of Facilities Controlled under SLFs, The Ministry of Land, Transport and Maritime Affairs, March 2011

conflicts between residents, personnel management, and accounting [15].

Facilities such as electric installations, gas facilities, and firefighting equipment are inspected and inspection results are reported in accordance with each relevant law. Another housing maintenance-related law, SLFS, requires buildings larger than a designated size to be under safety inspection and precise safety diagnosis.

The structures handled by SLFS are divided into first-class and second-class facilities by the sizes of facilities. The first-class facility designation includes buildings greater than 21-stories or larger than 50,000 square meters. The second-class facility designation includes 16- to 20-story buildings or those larger than 30,000 square meters.

The number of facilities under the control of SLFS (Table 3) is 54,940 (6,831 first-class and 48,109 second class structures), where 40,083 of the facilities are buildings, which is the largest share at $73 \%$. Most of the facilities $(51.3 \%$ or 24,808 structures) are in the metropolitan area including Seoul [16].

The data of the facilities controlled under SLFS are required to be collected in the Facility Management System. However, the targets of the system are limited to 16-story and taller buildings and the data supplied by the system have often been considered unreliable because the body that enters the building data (owner, management agent, contractor, etc.) tends to input false information in order to pass inspections and prevent a decrease in housing prices. Since the history data of buildings are not public, the system has been criticized for not being transparent in supplying data [17].

\section{Issues Of Safety Inspection For Multiple Dwellings In Korea}

The safety inspection of New York City targets buildings with more than six floors and examines not only the structural performance of buildings but also their overall conditions including site, ground, exterior, roof and rooftop, and interior. More specifically, the Housing Maintenance Code defines minimum criteria for health of residents, safety, fire protection, lighting, and maintenance and compensates for issues concerning the environment and quality of life that are likely to be overlooked in inspection of exterior walls and appurtenances.

In Japan, the targets of safety inspection are buildings with five floors or more. The inspection examines not only the structural performance of a building but also its site, ground, exterior, roof and rooftop, interior, and escape facilities. Thus, the whole of the building is checked. It is important to point out that items pertaining to quality of life such as the land around a building, lighting, ventilation, and presence of asbestos are also assessed. Those inspections are performed by professionals such as architects or safety inspectors qualified for special structures.

The safety inspection of buildings in Japan and the United States handles both structural aspects and the matters related to the environment and residents quality of life, and the history of such safety inspections is managed.

The safety inspection for buildings in Korea is limited to multiple dwellings with 16 floors or more. The range of the inspection targets is much narrower compared to Japan and the United States [18].

Expanding the scope of inspection is necessary because buildings shorter than 16 stories compose a 
Table 3: Conditions of Facilities Controlled under the SLFS

\begin{tabular}{c|r|r|r|r|r|r|r|r}
\hline Type & $\mathbf{2 0 0 3}$ & $\mathbf{2 0 0 4}$ & $\mathbf{2 0 0 5}$ & $\mathbf{2 0 0 6}$ & $\mathbf{2 0 0 7}$ & $\mathbf{2 0 0 8}$ & $\mathbf{2 0 0 9}$ & $\mathbf{2 0 1 0}$ \\
\hline Total & 33,295 & 36,507 & 38,929 & 42,157 & 45,745 & 48,298 & 51,645 & 54,940 \\
\hline Road & 5,255 & 5,906 & 6,291 & 6,867 & 7,566 & 7,778 & 8,409 & 8,177 \\
\hline Railroad & 1,445 & 1,525 & 1,567 & 1,611 & 1,794 & 1,835 & 1,915 & 2,119 \\
\hline Port & 229 & 238 & 244 & 253 & 258 & 262 & 288 & 297 \\
\hline Dam & 60 & 60 & 61 & 98 & 105 & 384 & 521 & 523 \\
\hline Building & 24,139 & 26,478 & 28,379 & 30,754 & 33,156 & 35,010 & 37,172 & 40,083 \\
\hline River & 554 & 566 & 577 & 597 & 719 & 753 & 952 & 1,161 \\
\hline Water \& Sewage, Landfill & 1,111 & 1,175 & 1,216 & 1,265 & 1,309 & 1,362 & 1,386 & 1,411 \\
\hline Retaining Wall & 361 & 395 & 423 & 512 & 612 & 675 & 753 & 856 \\
\hline Cut Slope & 141 & 164 & 171 & 200 & 226 & 239 & 249 & 314 \\
\hline
\end{tabular}

Note) Situation of Facilities Controlled under SLFs, The Ministry of Land, Transport and Maritime Affairs, March 2011

substantial portion of all the buildings in Korea (approximately 74\%) and small buildings have often been under poor safety management.

Above all, it is imperative to develop qualifications for safety inspection. In Korea, housing managers are required to conduct safety inspections. However, they have rarely been provided with education on architecture or construction. Enhancing their professional skills is an urgent necessity [19]. Safety inspection in Korea mainly handles the conditions and changes in structures, such as changes in a building, changes in a structure, and changes in loading conditions and foundations, whereas the safety inspection of Japan and the United States considers the housing environment such as the land around buildings, lighting, ventilation, presence of asbestos, and escape facilities including passages, hallways, and exits.

\section{Proposal Of Directions For Safety Inspection Of Multiple Dwellings In Korea}

\subsection{Changes in Items of Safety Inspection to Consider Quality of Life}

The items of the safety inspection in Korea mainly focus on structural matters of buildings [20]. A series of structure collapses in the 1990s have caused building safety inspections to focus on structural aspects. However, housing environment, quality of housing, and energy saving are receiving increased attention. Safety inspections in Korea need to include items for lighting, ventilation, presence of asbestos, firefighting, escape, and energy saving in order to respond to current issues including improvement in quality of life and eco-friendly buildings.

\subsection{Increase of Buildings under Safety Inspection and Establishment of Building History System}

Seoul enforces safety inspection on buildings with more than 150 families or with more than 16 floors, but 16-story or shorter buildings are not the target of safety inspection. Since the laws were enacted in 1995 after disastrous accidents of structure collapses, they mainly dealt with safety inspection of large facilities. Mid-rise multiple dwellings shorter than 16 stories thus have no legal safeguards. Performing safety inspections for these multiple dwellings is necessary. For example, Japan enforces safety inspection for five story and taller buildings and New York in the United States requires safety inspection for six story and taller buildings.

Considering the current trend that environment-friendly buildings are being given more consideration, the entities of building management need to adjust the building history system to include data related to energy saving policies for buildings (the operation-related saving system for existing buildings, the saving system for equipment, and materials using energy) and eco-friendly certifications (the energy efficiency rating system, the eco-friendly certification system, and the housing performance indication system). Through the system, the information on energy load and reduction can be collected.

In addition to eco-friendly information, data on disaster prevention needs to be added to the items of safety inspection. The laws of Japan stipulate inspections on escape facilities used for emergency. Since multiple dwellings taller than five stories account for a substantial share of the buildings of Korea, organizing building history and safety inspection systems is required.

\subsection{Development of Professional Manpower and Qualifications for Safety Inspection}

According to the laws of Japan, only skilled professionals, such as architects and inspectors qualified 
for inspection of special structures registered in the Japan Building Disaster Prevention Association, are permitted to conduct safety inspections for buildings. In Korea, housing managers can independently perform safety checks for multiple dwellings in accordance with the Housing Act. Even though housing managers are required to attend legal education courses, they have had few opportunities to study architecture and construction. Safety inspections of buildings are closely connected to the safety of the public and should therefore be implemented by professionals. Qualified architects, engineers, or concerned organizations would ideally be responsible for aspects of inspection that demand certain skills. Also, qualifications should vary according to current situations such as an enormous number of families residing in multiple dwellings and the diversity in life styles. Since a significant number of high-rise residential buildings accommodate many families in Korea, it is necessary to give preference to certifications on safety checks for buildings and facilities, optimal operation of community associations, and counseling works. In Korea, nearly $80 \%$ of the housing units are approximately twenty years old. Thus, developing certifications for facilities, pipelines, and finishing materials (e.g., outer walls, tiles) rather than main structural components is required. Establishing qualifications for advice and counseling about repair and reconstruction is necessary.

\section{Conclusions}

Korea has had construction-based housing policies. In the 2000s, the excessive construction of houses and social changes such as the low birth rate and improved quality of life have brought about an oversupply of housing units. The housing supply rate reached $110 \%$ and unsold new apartments have become a social issue. The policy of quantitative supply of housing is now forced to shift to rehabilitation of existing units and improvement in the quality of life.

Nearly $80 \%$ of multiple dwellings were found to be approximately twenty years old, and thus, the issues of maintenance, rehabilitation, and safety inspection of housing units are expected to be of importance. Therefore, the safety inspection systems of Japan and the United States were compared and analyzed in order to establish methods for proposing a future safety inspection system for multiple dwellings in Korea. This study presented several methods for instituting a sustainable safety inspection system for existing multiple dwellings in Korea. The results of the study are summarized below.

First, by researching the safety inspection systems for multiple dwellings in Japan and the United States, the state of the safety inspection systems and the policies for multiple dwellings in Korea were examined. Subsequently, the weakness of the Korean safety inspection systems and the requirements to revise them were discussed.
Second, the housing circumstances of Korea, Japan, and the United States were analyzed and compared, including laws on safety inspection for multiple dwellings, targets and items of inspection, qualifications for inspection, building history systems, and qualified professionals for safety inspection. Through the analysis and comparison, the differences between the systems of the three nations and the issues that need to be introduced in Korea were presented.

Third, based on the safety inspection experiences of Japan and the United States, new directions of safety inspection and methods to enhance current systems for multiple dwellings in Korea were proposed.

\section{Acknowledgements}

This work was supported by the National Research Foundation of Korea(NRF) grant funded by the Korea government(MEST) (No. 20120000723, No. 20110028794)

\section{References}

[1] S. H. Im. Housing Policies over Half a Century. Korea Land and Housing Corporation, (2002).

[2] The Ministry of Land, Transport and Maritime Affairs. Construction Economy Statistics, (2010).

[3] Statistic Korea. Population Census, (2005).

[4] The Ministry of Land, Transport and Maritime Affairs. Guidelines for City Planning to Develop Low-Carbon Green City, (2009).

[5] B. H. Oh. A Strategy to Develop Public Housing Finance, Korea Housing Finance Corporation, (2006).

[6] S. H. Park. A Study on Systems to Support Maintenance of Mid- and High-Rise Multiple Dwellings in Japan, Korea and the United States. Doctoral Dissertation, The University of Tokyo, (2009).

[7] Clair Report. Housing Policies of the United States. Council of Local Authorities for International Relations, (2006).

[8] The City of New York. Housing Maintenance Code, (2009).

[9] The City of New York. Building Code, (2010).

[10] P. S. Nivola. Distributing a Municipal Service: A Case Study of Housing Inspection. The Journal of Politics, 40, 59-64 (1978).

[11] New York City Department of Buildings. Strategic Plan, 2006-2009 (2006).

[12] The Japan Building Disaster Prevention Association. Standards for Regular Inspection Works for Special Structures, (2005).

[13] The Ministry of Land, Infrastructure, Transport and Tourism. Statute Book on Legal Inspections for Buildings, (2004).

[14] Mansion Mirai Net. Mansion Management Centers Web Site. Available at http://www.mankan.or.jp, (2010).

[15] The Ministry of Construction \& Transportation. A Report on Development of Maintenance and Repair Methods for MultiOwned Buildings, (2006). 
[16] The Ministry of Land, Transport and Maritime Affairs. Guidelines for Safety Inspection and Precise Safety Diagnosis for Facilities, (2010).

[17] C. H. Gwon. Examples of Successful Establishment of Preventive Maintenance Information Systems. Korea Infrastructure Safety \& Technology Corporation, (2007).

[18] E. Y. Sin. Methods to Alter Facilities under Special Law for Safety Management of Facilities. Korea Institute of Construction Engineering and Management. 10, 28-32 (2009).

[19] J. B. Lee. Measures for Efficiency of Maintenance of Multiple Dwellings, with AHP Technique. Korea Institute of Construction Engineering and Management, 7, $70-76$ (2006).

[20] J. Y. Jeon. Directions of Systemization and Development for Building Maintenance Field of Korea. Korea Institute of Construction Engineering and Management, 8, 19-21 (2007).

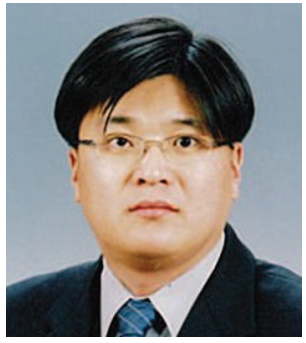

Sang-Hoon

Park received his $\mathrm{Ph}$. D. degree from Department of Architecture, Faculty of Engineering, in the University of Tokyo. Currently, he has been a research assistant professor in Yonsei University. His research interests are in the area of maintenance of apartment, Sustainability.

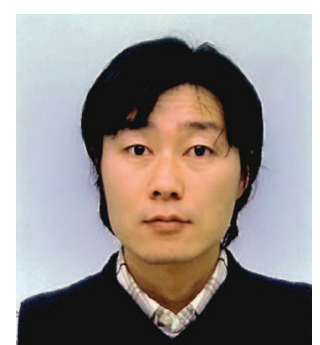

Cheonghoon

Baek received the $\mathrm{Ph}$. D degree from University of Tokyo, Japan on September, 2008. He is currently a senior researcher in KICT, Korea. His research interests are in the areas of sustainable architecture and renovation of existing housing.

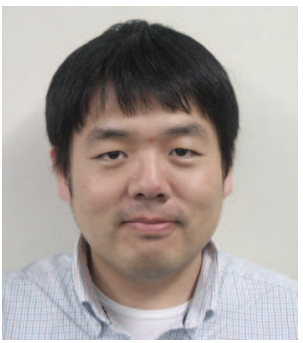

\section{Dong-Keon}

Kim received his MS degree from School of Civil and Environmental engineering in Georgia Institute of Technology. He then received his $\mathrm{Ph}$. D. degree from Department of Civil, Structural, and Environmental Engineering in University at Buffalo. Currently, he has been a senior researcher in Central Research Institute, Korea Hydro \& Nuclear Power. His research interests are in the area of continuum damage mechanics, finite element analysis, modeling of plasticity and earthquake engineering. 